\title{
Kernos
}

Revue internationale et pluridisciplinaire de religion grecque antique

3 | 1990

Varia

\section{The Oracle Given to Chaerephron on the Wisdom of Socrates. An Invention by Plato}

Mario Montuori

\section{OpenEdition}

\section{Journals}

Electronic version

URL: http://journals.openedition.org/kernos/994

DOI: 10.4000/kernos.994

ISSN: 2034-7871

\section{Publisher}

Centre international d'étude de la religion grecque antique

\section{Printed version}

Date of publication: 1 January 1990

ISSN: 0776-3824

\section{Electronic reference}

Mario Montuori, «The Oracle Given to Chaerephron on the Wisdom of Socrates. An Invention by Plato », Kernos [Online], 3 | 1990, Online since 19 April 2011, connection on 21 April 2019. URL : http:// journals.openedition.org/kernos/994; DOI : 10.4000/kernos.994 


\section{THE ORACLE GIVEN TO CHAEREPHON ON THE WISDOM OF SOCRATES. AN INVENTION BY PLATO*}

The historical character of the oracle's reply to Chaerephon's question as to whether any man was wiser than Socrates has been generally accepted by modern Socratic historiography. The historic authenticity of the Delphic pronouncement was not questioned by Schleiermacher, Hegel and Zeller and has since been confirmed by a long tradition of Socratic studies. By contrast, the perplexity, silence or denial of a few scholars seem little more than rare, paradoxical exceptions.

"To invent the deposition of a witness at a recent trial», wrote Gomperz, "and except by this fabrication to make contemporaries and posterity believe in an event of the utmost importance : who would wish to attribute to Plato such a purpose which is as stupid as it is dishonest ?» The Delphic answer, which by almost unanimous agreement has been accepted as evidence of an historical event, has therefore become "one of the most important documents on the philosophy and destiny of Socrates" and its historical character appeared to guarantee the authenticity of Plato's Apology as a Socratic document.

True; the Socratic image drawn by Plato in the Apology rests entirely on the reply made by the Delphic god, and Socrates' mission among men and his tragic destiny are both indissolubly tied to and derived from it. Maier was therefore perfectly right when he remarked that «the basis of the train of thought adopted by Plato in the Apology would collapse if the story relating to the answer of the oracle were to be considered as fiction». But as he had "no reason to doubt» the historic nature of the Delphic pronouncement, Maier himself was able to direct his investigations to endeavouring to discover whether it was possible to obtain from the Apology and from Crito, "and especially from Apology, an image of Socrates that was clearly designed and impersonal, and indeed intentionally faithful». Thus in the so-called Socratic dialogues, Socrates should be seen to speak and act as he does in the Apology.

* The question of the oracle given to Chaerephon has for the first time in the history of Socratic literature been at length discussed, documented and proved in my book Socrate. Fisiologia di un Mito, Firenze, Sansoni, 1974; english edition : Amsterdam J.C. Gieben, 1981. 
Maier's criterion for investigation, typically based as it is on the credibility of the Apology, can well be taken to represent the general trend of modern Socratic historiography. This is because all or nearly all attempts to interpret the person of Socrates historically are based on the presumed fidelity of the Apology to Socrates' conversation. Plato's Apology has remained the basis of every possible Socratic reconstruction, not only when a search is made for the real Socrates, but even when resort is made to the memories of Xenophon or the witness of Aristotle or the adaptation and agreement of the source with each other. And it has remained so because, as already said, the historical character of the oracle to Chaerephon gives to the Apology the value of an historical witness of the nature of Socrates' personality. The problem as to whether the story of the oracle to Chaerephon was the "witness of an historical event» has been easily solved, as, in fact, it has never been set.

Gigon's provocative thesis did not help in opening the discussion on the Delphic pronouncement and therefore on the historical truth of the Apology. It was he who, by denying the existence of historic evidence about Socrates, denounced at the same time the error made by modern Socratic historiography that had, in his opinion, mistaken the central figure of a philosophical poem for the historic person of Sophroniscus' son. Indeed, it so happened that the more radical Gigon's negations became, the greater became the vigour with which the credibility of the Apology as a Socratic document, and the truth of the answer of the Delphic oracle as its objective historic basis, were revalued. It would certainly be extremely helpful if the «admirable Apology at least, were not the subject of any doubt, in a problem as hopeless as that of Socrates, where everything is still under discussion; that is to say, if only it were possible to face all critics of the "marvellous document" with the concrete evidence of its historic reliability. Alas, this is not the case, for the simple reason that if the reliability of the Apology rests wholly or in part on the historical truth of the oracle to Chaerephon, and the figure of Socrates himself is built up on the basis of the profound bearing of the Delphic answer on his life and thought, none of those who have either rejected or accepted that famous Delphic pronouncement have ever given a satisfactory critical justification or their choice. No justification has been given by the historians, philosophers and philologists variously concerned with the case of Socrates; worse still, none has been given either by the historians of Greek religion or by the specialists of the Apollonian divination in Delphi. Some recent studies on Delphic religion have conspired to make the possibility of solving once and for all the problem of the story of the oracle's pronouncement even more 
difficult. Whilst admitting the difficulty of finding a critical explanation for the reason of the answer given by the oracle to Chaerephon, they confirmed nevertheless its historical truth and thus restored indirectly the documentary value of the Apology.

Thus it happens that all or nearly all the Socratic reconstructions suggested in modern times rest, in final analysis, on the following simple, if groundless premise : as it is not likely that the story of the oracle to Chaerephon about the wisdom of Socrates was invented by the Socratic legend, it must be considered a genuine witness of an historic fact. It thus guarantees the essential documentary reliability of the Apology and therefore permits a reconstruction of the Person of Socrates on a historic basis. In other words, it has been assumed by modern Socratic historiography that the oracle to Chaerephon is the objective historical basis of every possible Socratic interpretation, that is to say, the essential element which, on account of its very nature, guarantees the historical interpretation of every Socratic reconstruction. It is questionable however, whether the simple hypothesis that Plato would have been discredited in the eyes of his contemporaries if he had invented the deposition of a witness at a recent trial would suffice to justify historically the use of the pronouncement of the Delphic oracle as a basis of such Socratic interpretations. On the contrary, it looks as if we should speak of historical interpretations of Socrates, but of independent variations of the image of Socrates in the legend itself; at least until such time as the historic nature of the oracle to Chaerephon has been definitely proved by an historical research covering all relative fields. This is equally true when we drift from the objective ground of historicism. The real Socrates is then confused with a Socrates of our making; we avoid on principal testing the documentary reliability of the so-called Socratic sources and we accept them in their own original interpretive meaning.

This happens because, if it is true that the traditional Socratic sources are not really and truly historical sources, it is equally true that they can only be called Socratic interpretations when they interpret a well defined Socratic reality. It is indeed obvious in our case that the description of Socrates in the Apology, which is wholly and coherently repeated in the so-called Socratic dialogues, can only be considered as a Socratic interpretation by Plato, provided the Delphic reply to Chaerephon's question is reliable evidence of the historic event. If, however, the oracle to Chaerephon were, as a result of research, found to be an invention by Plato, then all his description of Socrates' personality would be shown to be his own free creation. One would then be right in believing that Plato 
had deliberately changed the historic personality of Socrates accused of $\dot{\alpha} \sigma \varepsilon \varepsilon_{\varepsilon} \alpha$ into that of Socrates beloved of Apollo and religious missionary.

In the first place, it seems essential to prove the historical truth of the Delphic pronouncement about the wisdom of Socrates. This is true if we take the oracle to Chaerephon to be the evidence of an historical fact which, by guaranteeing the reliability of the Apology, makes possible an historically based Socratic reconstruction. On the other hand, it is equally true if we consider the Apology to be literary evidence of Plato's interpretation of Socrates. This is necessary, because the reply of the oracle, which is so essential and characteristic in Plato's description of Socrates, represents, by common agreement, the objective historical basis of the Platonic interpretation on the one hand, and of the modern historiographic interpretation on the other. Until this proof, made necessary by the very existence of the Socratic problem, has been obtained, we shall never know, when speaking of Socrates, whether we are referring to an historical personage, historically definable, or to a symbol which can be interpreted in various ways, because it can be defined in various ways, a distant figure of myth and poetry, removed as such from the categories of historical interpretations. It is necessary and urgent therefore to clear up the dilemma and face the question of the historical nature of the Delphic oracle. This should be done by submitting to an exhaustive scrutiny, not only those elements of Platonic story concerning the oracle about the wisdom of Socrates, but also those elements that modern Socratic historiography has considered definitely relevant to the credibility of the story.

Is the story of the oracle, as it is believed, evidence about Socrates, the nature of his personality and his destiny; or is it an invention of Plato which changes the reality of Socrates $\alpha \sigma \varepsilon \beta \dot{\eta} \zeta$ into that of Socrates who has received from Apollo a religious mission for a whole people?

When we read Plato's Apology, we are struck by the tone with which Socrates tells his judges of the special favour shown him by the Delphic god, if we contrast it with the general tone of his self-defence. For instance, his request to them, twice repeated, to stop making a disturbance, his insistence on Chaerephon's impetuous character; the reminder of the exile he suffered and his return to the fatherland; things which Socrates himself takes for granted are known to his former companions; and lastly the old friendship, which Aristophanes had satirized 24 years earlier. But above all it is the awareness of having said something great which causes Socrates to hesitate and to interrupt his speech with several pauses. All this does not lead us to believe that on account of his natural modesty, Socrates had wished to lessen the 
solemnity of the declaration, because, shortly after, he did not hesitate to declare with shameless arrogance that he was the gift of a god to the city. There was no greater good, he said, than the mission he had persuaded, that the city should feed him at its expense in the Prytaneum, and if they killed him they would not easily find another man like him. Making our own a remark by Maier, if it is Plato who is speaking here, it would not be possible to describe more effectively the impression which the disciples had received from the master and his work. "If, on the other hand, it is Socrates who is speaking, it is difficult to think of anything more distressing and irritating than such boasting and selfglorification».

It is necessary therefore to suppose that Socrates' megalomania is to be attributed to his disciple; whereas the differences in tone show that, in this instance at least, Plato is a faithful interpreter of Socrates' words. This conjecture would also serve to confirm the fact that is was only on the presence of his judges, in order to defend himself, that Socrates decided to reveal to the Athenians the pronouncement about his wisdom which Apollo made through the Pythia, and which until then no one knew, not even his friends. If this is the case, we must ask whether it is likely that the impetuous Chaerephon was silent with everyone for so many years about the answer given by the Pythia, even during the nostalgia of exile, and that it was to his brother alone that he revealed it in secret. And who was this man? Plato does not even mention the name of such a witness, and never again refers to a brother of Chaerephon, but they had quarrelled with one another. We know that this brother hated him so much that Socrates had to give him a lesson on brotherly love. It is possible therefore that Chaerephon revealed the secret to him that the Apollo of Delphi had declared Socrates the wisest of men ? And who indeed was Socrates, or rather, what was the nature of his wisdom to provoke Chaerephon's question and the Pythia's answer? One wonders what the priests of Delphi knew about the wisdom of Socrates to enable them to answer Chaerephon's questions to whether there was anyone wiser than him. And even admitting that they knew about the wisdom of Socrates, were not such question and answer, however formulated, a negation in themselves of the morality professed at Delphi which, in opposition to the insolence of hybris, counselled a humble awareness of human limitations ? And again, when did Chaerephon question the Pythia about the wisdom of Socrates ? Did the oracle's reply alter the direction of Socrates' life and thought, and make him a different man to what he was before or did it simply make him aware that his dialectical vocation, already outstandingly developed, had a religious mission ? 
Why did Plato make no further reference to the reply of the oracle during the whole of his long literary career, even when he replied in Gorgias to

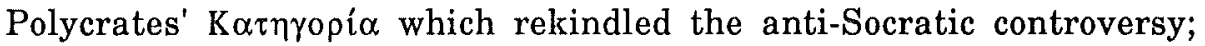
and not even in letter VII when he is probably speaking of Socrates in historical terms? And why is there no mention of such an important fact in any other contemporary work except, of course, the Apology attributed to Xenophon?

It is, to say the least, surprising that there is no reference whatsoever to the oracles on the comedies, not even in Aristophanes, either before or after the trial. It is even more surprising that there is no mention in oracular literature of an oracle like that to Chaerephon. Therefore, if no one has ever made reference to the oracle about the wisdom of Socrates, who then was the first to speak of it in his own Apology, Plato or Xenophon ? If, as it seems, it was Plato who wrote and circulated his own Apology of the Master and should the Delphic pronouncement be found on investigation to be merely an invention of Plato, is it possible that Plato wished to deceive us on such a subject, and if so, why?

It would appear then, that contrary to what has long been believed, the Delphic pronouncement on the wisdom of Socrates is not historical evidence about his wisdom, understood either as awareness of his own ignorance, or as youthful interest in natural science, or as dialectical investigation of men. The pronouncement is not evidence either of Apollo's sympathy, due to Socrates' special devotion to him at his Delphic shrine, and even less of a central and decisive event in Socrates' life, such as the change over or "conversion" from physics to moral philosophy which the Delphic oracle would have caused or helped to cause. In short, the oracle to Chaerephon is not, in fact «one of the most important documents about Socrates' philosophy and destiny» and in no way evidence of an historical fact; it is purely and simply an invention by Plato, in other words, the first root of the myth, dear throughout the centuries, of the just man condemned.

The inexplicable mystery of the oracle to Chaerephon in the history of Apollonian divination at Delphi has thus been solved. At the same time; the discovery that the oracular pronouncement about Socrates' wisdom is fiction, calls into question the reliability of the entire description of the Socratic personality.

If it is true that the description of Socrates in the Apology is built up entirely on the pronouncement of the God of Delphi, to which, a consequence, the mission to men and the tragic death are indissolubly bound, it is obvious that, once it has been shown that the oracle's 
pronouncement is an invention by Plato, the whole Socratic image derived from it should also be considered in the same light.

It is a fact that whilst no contemporary confirmed or disproved the oracular pronouncement of Socrates' wisdom, his image in the Apology and in the first Platonic dialogues, which were inspired by that pronouncement, were decidedly rejected. Once it has been shown, as we believe we have done, that the oracle to Chaerephon was invented by Plato, the whole description of Socrates in the Apology, based as it is on the oracle, should be re-examined as mythical and poetic creation.

As well as the Apology, the validity of those interpretations of the person of Socrates based on the presumed but never proven reliability of Socrates' speech at his trial, should also be called into question. If we look into the matter closely, not only the Apology, but all Plato's evidence, long considered to be the most reliable source, should be reexamined. This is because we must take into account the possibility that when inventing the oracular pronouncement, Plato deliberately altered the nature of the human and philosophical personality of Sophroniscus' son. In his first eristic dialogues, which derive their coherence from the story of the Apology, Plato may have introduced an entirely different person from the Athenian citizen who was indicted, tried and condemned for $\alpha \sigma \varepsilon \varepsilon \varepsilon \varepsilon \alpha$.

The discovery that the oracle to Chaerephon is an invention by Plato, no longer allows us to speak of Plato as a reliable Socratic source, and even, less as a privileged historic source. It is not possible either to speak of Plato's Socrates as an «interpretation" by Plato, because the Socratic "reality" itself, it seems, has been deliberately altered by Plato at its very root. It is also meaningless to change the object of Socratic research from the "historical" Socrates to the historically of Socratism, thus giving up "true" Socrates for a "truer" Socrates, because Plato's Socrates, which appeared to give us a "truer" Socrates, has been discovered on investigation to have been entirely invented by Plato.

The conclusion of our study of the Delphic pronouncement on the wisdom of Socrates, therefore, leads us to take up a position which is even more radical than that of Gigon. The Swiss scholar insisted that the source were literary, removed from reality and not historical. According to him it was not possible, therefore, to discover the historic Socrates beneath the idealized literary fictitious. The present investigation has found that Plato, quite simply, has not told us the truth. He profoundly altered the character of Socrates' personality (or at least we have to suppose this) and he gives us in point of fact the fictions and

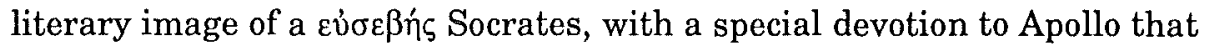


has nothing whatsoever to do with the Socrates indicted, tried and condemned.

It is true that in the course of his long literary career, Plato drew not one, but several Socratic images which sometimes contradict each other.

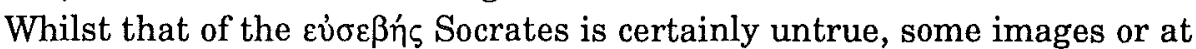
least one not based on Socrates' presumed $\varepsilon \dot{v} \sigma \varepsilon \varepsilon_{\varepsilon \varepsilon 1 \alpha}$ could be true. However, this objection, which is valid by conjecture, lacks confirmation. Until such time as it can be confirmed, the discovery of the fictitious nature of the oracle on which the most lively and attractive image of Socrates has been based, throws doubt on Plato's historical reliability.

It then remains to discover why Plato decided to describe to his contemporaries a Socrates fundamentally different from the man he knew, admired and loved. In other words, we must ask why he fabricated in the oracle the Chaerephon, a literary image of Socrates which, in point of fact, was the exact opposite of the impious man and corruptor who was known, not only to most of the Heliasts, but also to Aristophanes and Polycrates who had testified against him before and after his trial and condemnation.

Above all, we must question whether the discovery that Plato deliberately did not tell the truth, makes it still possible to make use of him as a source for discovering the historical personality of Socrates. In particular, we have to ask ourselves in which and in what measure the evidence of Plato is still useful, in view of the fact that the figure of Socrates in the Apology and in the eristic Dialogues has been found historically unacceptable, based as it is, on the fiction of the Delphic pronouncement.

Our findings in the fictitious nature of the oracular pronouncement do not however, end our research by enabling us to declare that it is impossible to discover Socrates' real personality. A new problem now arises : why did Plato do it? In other words, why did he have recourse to the fiction of the oracle to Chaerephon in order to make his contemporaries and posterity believe in an image of Socrates built up on an historical falsehood? Moreover, if Plato built up his image upon an historical falsehood, is it still possible to regard him as a reliable witness for the purpose of discovering the historical personality of Socrates?

In any case, once Plato's falsehood has been discovered, is it still possible to read him as a Socratic source? 
This means that, once we have reached the first root of the Socratic myth, our problem is to find Plato's real message within the origin and structure of the myth, in the hope that it will lead us to the true Socrates.

"La Margherita" Selva Antica

Mario MONTUORI

I - 05035 NARNI (Tr) 